
\title{
25 Research Suare \\ Open Nucleus Breeding Strategy for Fogera Cattle Breed in Ethiopia: Achievements and Lessons Learnt
}

\section{Assemu Tesfa Sendeku ( $\sim$ assemu546@gmail.com )}

Amhara Regional Agricultural Research Institute

Mekonnen Tilahun

Amhara Regional Agricultural Research Institute

Zelalem Asmare

Amhara Regional Agricultural Research Institute

Demelash Kassahun

Amhara Regional Agricultural Research Institute

Tewodross Bimerew

Amhara Regional Agricultural Research Institute

Wondimagegn Mengesha

Amhara Regional Agricultural Research Institute

Addisu Bitew

Amhara Regional Agricultural Research Institute

Eyasu Lakew

Amhara Regional Agricultural Research Institute

Mulugeta Meseret

Amhara Regional Agricultural Research Institute

\section{Research Article}

Keywords: Community based, Fogera cattle, Nucleus herd, Selection response

Posted Date: August 17th, 2021

DOI: https://doi.org/10.21203/rs.3.rs-787605/v1

License: (c) (i) This work is licensed under a Creative Commons Attribution 4.0 International License. Read Full License 


\section{Abstract}

Fogera cattle are one of the promising indigenous milk type local breed of Ethiopia. The objective of this paper was to evaluate the performance of Fogera breed under open nucleus breeding scheme. The work was done in two purposively selected districts (Gondar Zuria and Fogera) with community-based breed productivity improvement (CBBPI) as an approach. The collected data was analysed by GLM procedure of SAS for fixed factors estimation. Genetic parameters estimate was made by ASREML software for heritability and correlation. The overall milk yield of the nucleus herd was $2.26 \pm 0.794$ litter. From the total herd, best $10 \%$ and $25 \%$ of them give a respective milk yield of 3.31 and 2.87 litter; and some elite cows give an average of $5.45 \pm 0.73$ litter with a maximum yield of eight litters per day. The overall birth and weaning weight of nucleus herd calves was $21.30 \pm 0.06$ and $103.66 \pm 0.59 \mathrm{~kg}$, respectively. Heritability for birth and weaning weight was $0.24 \pm 0.09$ and $0.18 \pm 0.05$, respectively. The phenotypic and genotypic correlation with their respective standard error between birth and weaning weight was $0.0613 \pm 0.0075$ and $0.0712 \pm 0.0343$, respectively. For CBBPI program, 17 pure Fogera bulls were distributed to the two districts. The birth and weaning weight of the village calves was $23.77 \pm 0.21$ and $85.89 \pm 1.07$, respectively. Through the program, above 1000 households were benefiting through the breeding program, health, forage development and grazing land management. To share the achievements of the results in CBBPI program, popularization through filed days and innovation platforms; and documentation of each step via publications, videos and pictures was done. From the result, it can be concluded that the strategy implemented for the breed conservation "open nucleus breeding scheme" had shown progressive results and improvement was recorded. To widen the result and improve the livelihood of the farmer, scaling up of the activity should better be planned with stakeholders.

\section{Introduction}

Cattle are central to culture and to life in Africa. The African cattle breeds that exist today comprise a critical long-term asset. They also provide short-term income and the daily food and nutrition for some 800 million livestock keepers across Africa [1]. Indigenous livestock breeds form the backbone of livestock production because of their ability to survive and reproduce under stressful tropical environments $[2,3,4]$.

Although information on the status and trend of farm animals is limited, different indigenous breeds are found at different threat levels [5]; they are either declined or extinct [6]. At the moment breeds like Sheko cattle and fogera are highly threatened as a result of interbreeding with other breeds and change in production system, resulting in decline of the pure line $[7,8]$. These breeds are decreasing and deteriorating in terms of both population size and genetic quality due to paradigm shift in the existing farming system and production system, and farm size dynamics of the native habitat, higher intensity of off-take rate and in turn the subsequent genetic dilution $[9,10]$. From the review of Teweldemedhn [11], the major challenges in indigenous cattle production in Ethiopia were reported to be feed shortage, disease, inbreeding, and shortage of labor in their order of importance. Beyond this, the commercial 
livestock sector is also facing several new challenges in relation with the increased demand for livestock products [12].

The cattle population in Ethiopia is dominated by the indigenous zebu types that account 98.71 percent of the total population [11]. In the country the indigenous cattle have been traditionally selected for their adaptive traits [13] and the majority of milk was, therefore, produced from these local breeds. The national average lactation period per cow was estimated to be about six months and average daily milk yield per cow was about 1.32 liter [14]. Milk yield could be increased through within and between breed selection and crossbreeding with cattle from improved dairy breeds. The strategy currently employed in Ethiopia to increase milk yield is by crossbreeding [15] without neglecting the potential milk producers of local breeds like Fogera cattle.

Fogera cattle are one of the promising milk type local breed of Ethiopia that is widely adapted around Lake Tana of Amhara region. The breed in known for its relatively higher milk yield and traction power, better resistance to internal parasites infestation, and sound adaptability to water logged area attributed to its long legs [16]. Ethiopian farmers choose this breed as it tend to begin calving at an earlier age; their strength to plough the heavy clay soils found in the country's wetland areas; and the breed is valued for various social purposes, including, for example, as an important part of a bride's dowry $[1,17]$. Currently the breed is used as dam and sire line to make use of its respective mothering ability and large body frame; and considerable better milk yield and growth rate [7]. The unique value of this breed was recognized during the reign of the late Emperor Haile Selassie and in 1964 a Fogera cattle conservation and improvement center was established [1] at Gojjam province, Andassa ranch.

Andassa ranch, currently named as Andassa Livestock Research Center (ALRC) had exerted an improvement and conservation effort both on-station and on-farm level to safeguard the breed from extinction and decrement in its productivity since 1964. The center with its current name was shape since 1992 and start open nucleus breeding strategy to improve Fogera breed beyond conservation efforts. In the support of ALRC, Ethiopian Biodiversity Conservation [5] had indicated that they collected semen for cryo-conservation of Fogera cattle. The ex-situ conservation and improvement effort was done by own animal selection under the open nucleus breeding scheme; with community based breed productivity improvement (CBBPI) as an approach. The final goal of the breeding scheme was restocking the declining village Fogera cattle population and improving the livelihood of the farmer. The objective of this paper, therefore, was to evaluate the performance of nucleus herd at ALRC and evaluate the result of first term community based breed productivity improvement done under nucleus herd breeding scheme of Fogera cattle.

\section{Materials And Methods}

\subsection{Description of working sites}


Andassa Livestock Research Center (ALRC): is found at $587 \mathrm{~km}$ Northwest of Addis Ababa, and $22 \mathrm{~km}$ South of Bahir Dar city (capital of Amhara region), on the way to Blue Nile fall. The total area of the center is about 360 hectares out of which 310 are covered by pasture land and the rest 50 hectares is covered with bushes and different constructions. The center was established to conserve Fogera breed both in-situ and ex-situ approach. The center had above 600 nucleus herd animals for conservation and improvement strategy. Community based breed improvement program was implementing at two districts; those are known to have true-to-type Fogera cattle breed. These are:

Gondar Zuria district: the district is found in North Gondar of Amhara regional state. It is located $12^{\circ} 39^{\prime} \mathrm{N}$ latitude and $37^{\circ} 19^{\prime} \mathrm{E}$ longitude. The altitude of the district is $1982 \mathrm{masl}$ and the average annual rainfall range between 950 to $1035 \mathrm{~mm}$. The annual temperature ranges from $27^{\circ} \mathrm{C}$ to $33^{\circ} \mathrm{C}$. The total area coverage of the district is $114,983 \mathrm{ha}$. The cattle population was estimated to be 212,164 [18].

Fogera district: the district is found in South Gondar of Amhara regional state. It locates $11^{\circ} 46^{\prime}$ to $11^{\circ} 59^{\prime}$ latitude and $37^{\circ} 33^{\prime}$ to $37^{\circ} 52^{\prime}$ longitudes. The altitude ranges from 1774 to 2410 masl, and receives mean annual rainfall of $1216.3 \mathrm{~mm}$ (ranging from 1103 to $1336 \mathrm{~mm}$ ). The average minimum and maximum temperature of the district vary between $10.3^{\circ} \mathrm{C}$ to $27.2^{\circ} \mathrm{C}$. It has an estimated cattle population of 182729. The land, about $44.2 \%$ is arable and $20 \%$ is irrigated, $22.9 \%$ for pasture, $1.8 \%$ forest or shrub land, $3.7 \%$ is water, and the remaining $7.4 \%$ is considered degraded land [19]. Figure 1 (right) indicates the working districts.

\subsection{Description of Fogera breed}

With its distinctive combination of a black muzzle, black inner ears, a black, white and grey coat colour, and its long legs and tail, the Fogera are one of the most iconic cattle breeds of Ethiopia. Found in the district bordering Lake Tana (Fig. 1 left), Ethiopia's largest lake and the source of the Blue Nile, the breed is particularly well adapted to wet soils and swampy areas and cop adapted to wet soils and swampy areas and copes well with the heavy fly, parasite and disease well with the heavy fly, parasite and disease infestations, as well as low quality of feed, that characterizes this challenging environment [1]. The breed (Fig. 2) is also characterized with short, stumpy, pointed horns; hump ranges from thoracic to cervicothoracic; dewlap is folded and moderate to large in size; docile temperament; used for draught, milk and meat $[20,21]$.

\subsection{Breeding strategy}

The center follows open nucleus breeding scheme (Fig. 3), to improve milk yield of Fogera cattle. In the strategy, improved bulls from the nucleus had transported to community (village) herd and selected heifers to the nucleus herd. In the nucleus herd, animals are grouped based on their milk yield and pedigree. A single herd had 40 to 50 cows with one bull and mating is natural.Calves had free access to suckle their dams for the first four days to ensure that they consume enough colostrum; they were then separated from their dams and allowed to partially suckle (two teats) at milking times until weaning. 


\subsection{Community Based Breed Productivity Improvement (CBBPI)}

As a part of open nucleus breeding strategy, community-based breed productivity improvement is the implementation program of the strategy at the village herd. For the implementation, through participation of researchers and experts, two districts based on presence of true to type Fogera cattle (50\%), Accessibility and presence of knowledgeable farmers (25\%) and others like willingness of farmers, communal grazing land and enough land for feed development (25\%) was selected. After selection, community discussion was done on points like the importance and productivity of the breed, its value for them and the need of the conservation and improvement strategy. After the consensus built with the community, farmers were selected to hold the breeding bull and serve the community. Those farmers were selected based on wealth status, cattle management ability, and presence of better educational background. And the bull was given based on written contractual agreement for four years' service and after to make him own property.

\subsection{Data analysis}

The collected data was analysed by general linear model (GLM) procedure of SAS [22] software. Milk yield performance was separately analysed by using period (Period 1, 2, 3, 4, and 5), category (10 and 25 percent of the herd), and breeding group (group I, II, III, and IV) as a fixed factor. Pre-weaning growth (birth weight and weaning weight) was analysed using sex and year for nucleus herd; and district, year, sex, and season of birth for CBBPI data as a fixed factor. The following GLM models was used for birth and weaning weight for both sites.

$Y_{i j k l}=\mu+B_{i}+D_{j}+X_{k}+S_{l}+e_{i j k l}$

Where, Yijklm $=\mathrm{m}^{\text {th }}$ record of $\mathrm{i}^{\text {th }}$ year, $\mathrm{j}^{\text {th }}$ season, $\mathrm{k}^{\text {th }}$ sex and $\mathrm{t}^{\text {th }}$ parity

$\mu=$ overall mean

$B_{i}=$ effect of $i^{\text {th }}$ year of birth

$D_{j}=$ effect of $j^{\text {th }}$ district

$X_{k}=$ effect of $k^{\text {th }}$ sex

$S_{1}=$ effect of $I^{\text {th }}$ season

$\mathrm{e}_{\mathrm{ijk} \mathrm{km}}=$ random error associated with each observation

ASREML [23] a statistical package that fits linear mixed models using Residual Maximum Likelihood (REML), was used to estimate the selected genetic parameters. To fit the models based on the data (Table 1), the data was arranged in to performance data (birth weight and weaning weight) and pedigree 
data (animal, sire and dam ID) based on the guidance of the software. Genetic parameters were estimated for heritability and correlation for birth and weaning weight. The fixed effects (sex, season and year) were included in the mixed model after they are checked for their significance effect via GLM procedure of SAS. The variance components and heritability were estimated using a uni-variate animal model, indicated below.

\section{$Y=X_{b}+Z_{1 a}+Z_{2 m}+Z_{3 c}+e$}

Where, $\mathbf{Y}$ is the vector of records; $\mathbf{b}$ is vector of fixed effects; $\mathbf{X}$ is incidence matrix of fixed effects; $\mathbf{a}$ is vector of direct additive genetic effect; $\mathbf{m}$ is vector of maternal additive genetic effect; $\mathbf{c}$ is vector of permanent environmental effect; $\mathbf{Z 1}$ is incidence matrix for direct additive genetic effect; $\mathbf{Z 2}$ is incidence matrix for maternal additive genetic effect; $\mathbf{Z} 3$ is incidence matrix for permanent environmental effect and $\mathbf{e}$ is vector of random errors

Table 1

Number of observation used for genetic parameter estimation

\begin{tabular}{|lll|}
\hline Type of data & \multicolumn{2}{l|}{ Genetic parameter estimation } \\
\cline { 2 - 3 } & Birth weight & Weaning weight \\
\hline Animals used & 1497 & 1315 \\
\hline Progeny with unknown sires & 164 & 141 \\
\hline Sire & 55 & 53 \\
\hline Dam & 742 & 742 \\
\hline
\end{tabular}

\section{Result And Discussion}

\subsection{Nucleus herd achievements 3.1.1. Milk yield performance}

The result of the data (Table 2) indicated that through the advancement of year, milk yield was improved mainly since from 2008. The lowered milk yield during the period of 2005-2007 was due to the recorded inbreeding in the herd. The gradual increment was due to the subsequent selection based on milk yield. From the total herd, $10 \%$ and $25 \%$ of them had milked a respective average milk yield of 3.31 liter and 2.87 liter (Table 3); this result had an increment compared with the average milk yield of 3.04 and 2.62 liter [24] for respective best $10 \%$ and $25 \%$ of similar herd. The predicted 200 and 305 days milk yield of the best 10 and $25 \%$ of the herd was reported in Table 3 . As Table 4 presents, the group herd had variations in milk yield performance as they are group based on their milk yield performance. Among the entire herd, some 
elite cows give an average of $5.45 \pm 0.73$ with a maximum yield of eight litters; and this indicated that the selection response of the breed is higher.

The milk yield of the current study was higher than 1.65liter for Horro breed [25], 1.8 liter [26], $1.8 \pm 0.13$ liter [15] and $1.7 \pm 0.1 \mathrm{~kg}$ for Boran breed [27], $1.8 \pm 0.54$ liter [28], and $1.7 \pm 0.03$ liter for Arado breed [29]; and lower than $2.1 \pm 0.04$ liter for Begait breed [13], $2.79 \pm 0.06$ liter for Sheko breed [6], and $2.11 \pm 0.06$ liter for Mursi breed [30].

Table 2

Least square means of daily milk yield in different periods

\begin{tabular}{|llll|}
\hline Breeding period & N & Daily Milk Yield & Standard Error \\
\hline Period 1 (2002-2004) & 13958 & 2.30 & 0.009 \\
\hline Period 2 (2005-2007) & 8504 & 1.92 & 0.008 \\
\hline Period 3 (2008-2010) & 31657 & 2.13 & 0.008 \\
\hline Period 4 (2011-2013) & 10754 & 2.39 & 0.01 \\
\hline Period 5 (2014-2017) & 10114 & 2.43 & 0.071 \\
\hline
\end{tabular}

Table 3

Average daily milk yield performance and Predicted milk yield of Fogera cattle

\begin{tabular}{|lllll|}
\hline Parameters & $\begin{array}{l}\text { Daily milk } \\
\text { yield }\end{array}$ & $\begin{array}{l}\text { Predicted Milk yield } \\
\text { at100days }\end{array}$ & $\begin{array}{l}\text { Predicted Milk yield at } \\
\text { 200days }\end{array}$ & $\begin{array}{l}\text { Predicted Milk yield at } \\
\text { 305days }\end{array}$ \\
\hline $\begin{array}{l}\text { Overall } \\
\text { mean }\end{array}$ & 2.03 & 242.82 & 430.18 & 578.26 \\
\hline $\begin{array}{l}\text { Best 10\% } \\
\text { mean }\end{array}$ & 3.31 & 380.44 & 669.89 & 883.64 \\
\hline $\begin{array}{l}\text { Best 25\% } \\
\text { mean }\end{array}$ & 2.87 & 326.75 & 585.32 & 772.83 \\
\hline $\begin{array}{l}\text { Maximum } \\
\text { Minimum }\end{array}$ & 4.55 & 493.5 & 858 & 1194 \\
\hline
\end{tabular}


Table 4

Milk yield performance of the grouped herd

\begin{tabular}{|llllll|}
\hline Breeding Group & Herd type & \multicolumn{4}{c|}{ Milk yield (litter) } \\
\cline { 3 - 6 } & & Mean & SD & Min & Max \\
\hline 1 & Fogera G 1 & 2.24 & 0.731 & 0.7 & 5.5 \\
\hline 2 & Fogera G II & 2.52 & 0.863 & 0.6 & 6.1 \\
\hline 3 & Fogera G III & 2.05 & 0.814 & 0.4 & 7.2 \\
\hline 4 & Fogera G IV & 2.18 & 0.707 & 0.6 & 4.5 \\
\hline
\end{tabular}

\subsubsection{Birth and weaning weight performance}

The overall birth and weaning weight of nucleus herd calves was $21.30 \pm 0.06$ and $103.66 \pm 0.59 \mathrm{~kg}$, respectively. The result was comparable with the report of [16] for the same breed. As indicated in Table 5, the result had shown an improvement from year to year which the response for selection is done on the breed. The result for birth weight was lower than the report of [31, 32, 33, 34, 17], and higher than [6, 35] for different Ethiopian local breeds. The weaning weight (Table 5) was higher than the report of [33, 32, $34,17,36,6]$. These differences might be occurred due to difference in breeding objectives of the breeds.

Table 5

Least square means of birth and weaning weight

\begin{tabular}{|lllll|}
\hline Parameters & $\mathrm{N}$ & Birth weight $(\mathrm{kg})$ & $\mathrm{N}$ & 240 day weight \\
\hline Overall & 1975 & $21.30 \pm 0.06$ & 1426 & $103.66 \pm 0.59$ \\
\hline Sex & \multicolumn{2}{|c}{$*$} & & $* *$ \\
\hline Female & 1131 & $20.92 \pm 0.09$ & 805 & $101.91 \pm 0.93$ \\
\hline Male & 1075 & $21.86 \pm 0.09$ & 766 & $108.50 \pm 0.95$ \\
\hline Year & & $* \star *$ & & $* *$ \\
\hline $1997-2000$ & 438 & $21.67 \pm 0.14^{\mathrm{b}}$ & 408 & $107.87 \pm 1.11^{\mathrm{b}}$ \\
\hline $2001-2004$ & 385 & $21.80 \pm 0.14^{\mathrm{b}}$ & 340 & $102.76 \pm 1.21^{\mathrm{c}}$ \\
\hline $2005-2008$ & 408 & $21.07 \pm 0.14^{\mathrm{c}}$ & 271 & $94.73 \pm 1.36^{\mathrm{d}}$ \\
\hline $2009-2012$ & 421 & $19.53 \pm 0.14^{\mathrm{d}}$ & 337 & $104.53 \pm 1.22^{\mathrm{bc}}$ \\
\hline $2013-2015$ & 323 & $22.88 \pm 0.16^{\mathrm{ab}}$ & 70 & $116.14 \pm 2.67^{\mathrm{a}}$ \\
\hline $2016-2018$ & 231 & $23.83 \pm 0.59^{\mathrm{a}}$ & 145 & $101.45 \pm 1.71^{\mathrm{c}}$ \\
\hline
\end{tabular}




\subsubsection{Genetic parameter estimate}

Direct heritability for birth and weaning weight was $0.24 \pm 0.09$ and $0.18 \pm 0.05$, respectively (Table 6). Higher result for respective birth weight and weaning weight of $0.38 \pm 0.32$ and $0.22 \pm 0.25$ was reported by [37] at the same center. This difference might be due to management difference that influences the environmental part of the estimated genetic parameter. The phenotypic and genotypic correlation with their respective standard error between birth and weaning weight was $0.0613 \pm 0.0075$ and $0.0712 \pm$ 0.0343 , respectively. A lower phenotype $(0.05 \pm 0.02)$ and higher genotype $(0.6 \pm 0.23)$ correlation was reported by [38 for Fogera cattle breed at Metekel Fogera cattle conservation site. Higher direct heritability estimate was reported to be $0.68 \pm 0.09$ and $0.52 \pm 0.1$ [39], and $0.4 \pm 0.1$ and $0.47 \pm 0.1$ [40] for birth and weaning weight, respectively.

Table 6

Estimates of variance components and heritability measurements with their standard errors (SE) for growth traits

\begin{tabular}{|c|c|c|}
\hline \multirow[t]{2}{*}{ Model } & \multicolumn{2}{|l|}{ Traits } \\
\hline & BWT & WWT \\
\hline$\sigma^{2} a$ & 1.16563 & 303.192 \\
\hline$\sigma^{2} m$ & 0.151917 & 0.000000201 \\
\hline$\sigma^{2} c$ & 0.337094 & 26.1766 \\
\hline$\sigma^{2} e$ & 3.92704 & 1342.68 \\
\hline$\sigma^{2} p$ & 5.582 & 1672 \\
\hline$h^{2} a$ & $0.2088 \pm 0.0695$ & $0.1813 \pm 0.0539$ \\
\hline$h^{2} m$ & $0.0272 \pm 0.0492$ & $0.0000 \pm 0.0000$ \\
\hline$c^{2}$ & $0.0604 \pm 0.0496$ & $0.0157 \pm 0.0336$ \\
\hline $\mathrm{r}_{\mathrm{am}}$ & - & - \\
\hline $\log L$ & -2012.29 & -5462.11 \\
\hline \multicolumn{3}{|c|}{$\begin{array}{l}\sigma^{2} a=\text { direct genetic variance; } \sigma^{2} \mathrm{~m}=\text { maternal genetic variance; } \sigma^{2} \mathrm{c}=\text { maternal permanent } \\
\text { environmental variance; } \sigma^{2} e=\text { the residual variance; } \sigma^{2} p=\text { phenotypic variance; } h^{2} a=\text { direct } \\
\text { heritability; } h^{2} m=\text { maternal heritability; } c^{2}=\text { the fraction of total variance that corresponds to maternal } \\
\text { permanent environmental effect; } r_{a m}=\text { direct- maternal genetic correlation }\end{array}$} \\
\hline
\end{tabular}




\subsection{Community based breed productivity improvement (CBBPI)}

\subsubsection{Birth and weaning weight achievements}

Since 2012, the center had work on village breed improvement from the entire herd of the community. But after 2013, the implementation of open nucleus breeding scheme was done and selected bulls, based on their estimated breeding value and physical soundness, from nucleus herd were distributed to the selected villages. Since then, 17 pure Fogera bulls were distributed in two terms for both working districts. In first term (four year period), the mating bulls were transferred to the keeping farmers based on written agreement. The birth and weaning weight (at 8 month age) of the village herds born from CBBPI was $23.77 \pm 0.21 \mathrm{~kg}$ and $85.89 \pm 1.07 \mathrm{~kg}$, respectively (Table 7). The average weaning age was lowered from one year to 8 months. Based on the monitoring data the average birth and weaning weight of calves born by local bull of the area was 20.21 and $85.14 \mathrm{~kg}$ (at one year age), respectively. From this it can be appreciated that, through the open nucleus breeding program, there was an improvement in productivity beyond the conservation effort.

As a strategy, community based breed productivity improvement, includes different aspects of activity besides the breeding program. These activities, done in relation of the breeding program was strategic deworming and vaccination through flock monitoring strategy, grazing land improvement and introduction of new water logged tolerant grass specious and fattening technology demonstration; those all allow to improve the production improvement and the livelihood of the farmers. Above 1000 households are benefiting in the strategy through the CBBPI. Through the first term of the breeding program, above 38 castrated bulls fattened (Fig. 4); above 24,000 cattle covered by health treatment and Elephant grass, four water logging tolerant grass cultivars were introduced to alleviate feed problem of the area. 
Table 7

Least squares means $(+\mathrm{SE})$ of birth and weaning weight of village herd

\begin{tabular}{|lllll|}
\hline Parameters & $\mathbf{N}$ & Birth weight & $\mathbf{N}$ & Weaning weight \\
\hline Overall & $\mathbf{5 6 7}$ & $23.77 \pm 0.21$ & 293 & $\mathbf{8 5 . 8 9} \pm 1.07$ \\
\hline District & & $*$ & & $* *$ \\
\hline Fogera & 372 & $24.01 \pm 0.26$ & 190 & $86.44 \pm 1.29$ \\
\hline Gondar zuria & 195 & $23.31 \pm 0.33$ & 103 & $84.54 \pm 1.92$ \\
\hline Year & & $*$ & & $*$ \\
\hline 2015 & 207 & $23.08 \pm 0.33^{\mathrm{ab}}$ & 108 & $86.16 \pm 1.53^{\mathrm{b}}$ \\
\hline 2016 & 158 & $24.17 \pm 0.34^{\mathrm{a}}$ & 87 & $85.56 \pm 1.48^{\mathrm{b}}$ \\
\hline 2017 & 107 & $24.52 \pm 0.36^{\mathrm{a}}$ & 98 & $87.49 \pm 3.05^{\mathrm{a}}$ \\
\hline 2018 & 95 & $21.75 \pm 0.62^{\mathrm{c}}$ & - & - \\
\hline Sex & & $*$ & & $\mathbf{N S}$ \\
\hline Male & 277 & $24.15 \pm 0.30$ & 137 & $86.60 \pm 1.84$ \\
\hline Female & 290 & $23.45 \pm 0.27$ & 156 & $85.30 \pm 1.24$ \\
\hline Season & & NS & & $*$ \\
\hline Dry & 388 & $23.27 \pm 0.35$ & 209 & $84.27 \pm 2.35$ \\
\hline Wet & 179 & $23.75 \pm 0.56$ & 84 & $87.51 \pm 1.05$ \\
\hline
\end{tabular}

\subsubsection{Popularization, documentation and Farmers perception on CBBPI}

To popularize the activity and increase the participant farmers and districts, field day with different stakeholders of about 228 participants (Bureau of Agriculture, Universities, Ethiopia Institute of Biodiversity Conservation, zone to kebele offices, farmers and NGO's) was held mainly to indicate the efforts exerted on the breed improvement and conservation; share tasks for "hands-together" for the use of the resource; popularize the activity and develop scaling up modality to other target areas.

As CBBPI activities are long lasting, documentations had been done in every and each journey of the activity, which allow to see the drawbacks, identified challenges, take corrective measures, and further developing guidelines to other users and share the experiences to other areas. In this regard, CBBPI activity on Fogera cattle had documented in different forms viz. via videos, photos, publications (journals and proceedings) and other written documents. 
Participant farmers, getting a calve (Fig. 5) from the improvement effort, had "acknowledged Almighty GOD for having the cattle phenotype of their elder fathers". All farmers are well satisfied by the service delivered in relation to the conservation and improvement activity to improve the production environment. Non-participating farmers of neighboring gotes, kebeles and districts requests the research center to expand the conservation and improvement work with their vicinity.

\section{Major Challenges Of Cbbpi Of Fogera Cattle 1: Over flooding of Lake Tana:}

the lake, always over flood to the grazing land and make stagnant water for several months that lead disease outbreak and damage on the grazing land.

\section{2: Invasive weeds:}

in both sites, the grazing land had covered by unpalatable weeds like Amekela (Asracantha longifolia) and water body invasive weeds (water hyacinth) (Fig. 6 left) share the land and aggravate cattle disease. Based on the report of EBI [5] so far, close to 35 invasive weed species are identified in Ethiopia, and they cause biodiversity loss by competing native species for feed and habitat and altering the physical environment in a way that excludes native species. From which, water hyacinth (Eichhornia crassipes) was a lead that have a big effect on water body animals and livestock species depending their feed on grazing.

\section{3: Shift of production system:}

the dominant livestock-crop mixed production system of the areas was currently dominated by crop production and diversification that change the grazing lands to crop production.

\section{4: Genetic erosion:}

intact male Fogera bulls (Fig. 6 right) are currently get better price to the neighbouring countries market (like Sudan and Djibouti). This, with absence of marketing policy for border live animals, challenges both the conservation and improvement strategy.

\section{Conclusion And Lessons Learnt}

$\sqrt{ }$ In the current study, the result across year and period had shown an inconsistence result; which might be attributed to the presence of variable management practices adopted by the center. On the other hand, the result had indicated an improvement in the production performance of the breed that indicated the potential for selection is higher in the breed. 
$\sqrt{ }$ The community conservation and improvement strategy was a big entry point to assure the conservation effort, restocking of the declined village heard and improve the livelihood of the farmers. .

$\sqrt{ }$ Cumulative effort viz. breeding, forage, health and extension play a great role to sustain the conservation and improvement effort implemented under open nucleus breeding strategy.

\section{Future Directions}

With the above bold conclusions, the following recommendations are made to further strengthen the conservation and improvement effort of the breed.

- Strong linkage and follow up of the community should be done.

- The production environment of the conservation and improvement sites should be strengthen to improve the livelihood of the farmers through optional income generating activities

- Developing a reproductive technology and biotechnology unit to safe guard the breed from extinction by natural and/or manmade hazards had better be planed and implemented.

- Scaling up of the activity should better be planned with integrated approach of different stakeholders

\section{Declarations}

\section{Data Availability}

The raw data used to support the findings of this study are restricted by the institution in order to protect patient privacy. If necessary, contact the corresponding author.

\section{Conflicts of Interest}

The authors declare that they have no conflict of interest.

\section{Author's contribution}

A.T.S. had develop the manuscript; M.T., Z.A., D.K. had participate in data management and analysis; T.B., W.M., A.B., E.L. and M.M. had collect and fill the data to MS-excel. All authors have read and approved the manuscript.

\section{Ethics approval and consent to participate}

Not applicable. 


\section{Consent for publication}

Not applicable.

\section{Acknowledgements}

The authors had acknowledged district and kebele experts those are participating in the conservation and improvement strategy of the breed. On top of this authors extend their gratitude to partner organizations for their kind partnership and unreserved help for the effort made on the center. The heart felt acknowledgement was for Ethiopian Institute of Agricultural Research for their unlimited budget support. Farmers participating on the conservation and improvement strategy and keeping the breed are kindly acknowledged by the authors.

\section{References}

1. T. Dessie and O. Mwai, (editors), "The story of cattle in Africa: Why diversity matters" Nairobi, Kenya: International Livestock Research Institute, Rural Development Administration of the Republic of Korea and the African Union-InterAfrican Bureau for Animal Resources., Nairobi, Kenya, 268 pages, 2019.

2. N. Assan $<\mathrm{bi}>, "</ \mathrm{bi}>$ Genetic improvement and utilization of indigenous cattle breeds for beef production in Zimbabwe<bi >:</bi> Past, Present and Future Prospects"<bi $></$ bi $>2012<$ bi $>.</$ bi $>$

3. G. Shiferaw, "Reproductive and productive performance of Kereyu Sanga cattle in Fentalle District of Oromia Region, Ethiopia”. Journal of Cell and Animal Biology; Vol. 8(2), pp. 28-33, February 2014. DOI: $10.5897 / J C A B 2014.0404$

4. O. Mwai, O. Hanotte, Y. Kwon and S. Cho, "African Indigenous Cattle: Unique Genetic Resources in a Rapidly Changing World”. Asian Australas. J. Anim. Sci. Vol. 28, No. 7: 911-921 July 2015. http://dx.doi.org/10.5713/ajas.15.0002R

5. EBI (Ethiopian Biodiversity Institute), "Ethiopia's Fifth National Report to the Convention on Biological Diversity". Government of the Federal Democratic republic of Ethiopia; May 2014.

6. E. Bayou, A. Haile, S. Gizaw, Y. Mekasha, "Evaluation of nongenetic factors affecting calf growth, reproductive performance and milk yield of traditionally managed Sheko cattle in southwest Ethiopia”. SpringerPlus 4:568. 2015.

7. A. Tesfa, D. Kumar, S. Abegaz and G. Mekuriaw, “Conservation and Improvement Strategy for Fogera Cattle: A Lesson for Ethiopia Ingenious Cattle Breed Resource”. Hindawi Publishing Corporation; Advances in Agriculture. Volume 2017.

8. IBC (Institute of Biodiversity Conservation), "The state of Ethiopia's farm animal genetic resources: country report, A Contribution to the First Report on the State of the World's Animal Genetic Resources"; IBC, Addis Ababa, Ethiopia; 2004. 
9. IBC (Institute of Biodiversity Conservation), "Domestic animal diversity, Some of Ethiopia's domestic animal diversity"; 2012.

10. A. Kebede, L. Yeheyes, T. Eshetie, and G. Zeleke, "Production system shift and land fragmentation on livestock production in Fogera district: with special emphasis to the indigenous Fogera cattle breed"; in Proceedings of the International Workshop on Farm Size Dynamics in East and Southern Africa, Bahir Dar, Ethiopia; 2013.

11. T. M. Weldegerima, "Characterization of productive and reproductive performances, morphometric and challenges and opportunities of indigenous cattle breeds of Ethiopia: A review". International Journal of Livestock Production; Vol. 9(3), pp. 29-41, March 2018. DOI: 10.5897/IJLP2017.0426

12. G. Yifter, "Assessment of calf crop productivity and total herd life of Fogera cows at Andassa ranch, Northwestern Ethiopia". M.Sc. Thesis. Alemaya University, Alemya, Ethiopia; 2001.

13. G. Tewelde, Y. Sintayehu, B. Sandip, "Some morphometrical, production and reproduction traits of Begait cattle reared in Tigray region of Ethiopia". Wayamba J.Anim. Sci.-ISSN: 2012-578X; P1571 P1585, 2017, First Submitted June 08, 2017.

14. Central Statistical Agency of Federal Democratic Republic of Ethiopia, "Agricultural sample survey 2012/13 [2005 E.C.]," Volume II, Report on Livestock and Livestock Characteristics, Addis Ababa, Ethiopia, 2013.

15. G. Gebreyohannes, S. Koonawootrittriron, M. A. Elzo and T. Suwanasopee, "Variance Components and Genetic Parameters for Milk Production and Lactation Pattern in an Ethiopian Multibreed Dairy Cattle Population". Asian Australas. J. Anim. Sci. Vol. 26, No. 9: 1237-1246 September 2013. http://dx.doi.org/10.5713/ajas.2013.13040

16. A. T. Sendeku, “Genetic parameter estimate for performance traits of Fogera cattle". LAP LAMBERT Academic publishing. ISBN 978-3-659-76247-5; 2015.

17. W. Zewdu, M. Wurzinger, D. Tadele and J. Sölkner, “Potential of indigenous animal genetic resources as an adaptive mechanism on climate change: The case of Mahibere-Slassie composite cattle breed". Proceeding of Agricultural economics society of Ethiopia, 2004.

18. M. Fenta, "Adoption of Improved Chickpea Technologies in North Gondar Zone of Ethiopia: The Case of Gondar Zuria District". M.Sc. Research Thesis; University of Gondar, Ethiopia; November, 2017.

19. K. Alemayehu, D. Kebede, E. Girma, "Survival and population viability of Fogera cattle (Bos indicus, Zenga Type) in North West Amhara, Ethiopia". Global Journal of Animal Breeding and Genetics. ISSN: 2408-5502 Vol. 3 (6), pp. 181-187, September, 2015.

20. J.E.O. Rege and L.C. Tawah, "The state of Africa cattle genetic resource II". 1999.

21. DAGRIS, "Domestic Animal Genetic Resources Information System (DAGRIS)" (eds. S. Kemp, Y. Mamo, B. Asrat and T. Dessie). International Livestock Research Institute, Addis Ababa, Ethiopia. 2007. http://dagris.ilri.cgiar.org

22. SAS (Statistical Analysis System) Software Version 9.00; SAS Institute Inc., Cary, NC, USA; 2002.

23. A.R. Gilmour, B.R. Cullis, S.J. Welham and R.Thompson, "ASREML reference manual". NSW Agriculture Biometric Bulletin No 3. NSW Agriculture, Orange, NSW, Australia, pp210; 1999. 
24. A. Bitew, M. Taye, A. Kebede, G. Mekuriaw, A. Tassew, T. Mulugeta and G. Goshu, "Milk yield and calf growth performance of cattle under partial suckling system at Andassa Livestock Research Centre, North West Ethiopia”. Livestock Research for Rural Development 22 (8) 2010.

25. M. Agere, H. Aynalem, D. Tadelle, M. Yoseph, “On farm characterization of Horro cattle breed production systems in western Oromia, Ethiopia”. Livest.Res.Rural Dev.24(6) 2012.

26. T. Solomon, D. Tadelle and K. Kefelegn, "On-Farm Phenotypic Characterization of Boran Cattle Breed in Dire District of Borana Zone, Oromia Region, Ethiopia". MSc Thesis Abstracts, School of Animal and Range Sciences of Alemaya University, Volume I (1980-2013); 2011.

27. H. Aynalem, A. Workneh, K. Noah, D. Tadelle and T. Azage, "Breeding strategy to improve Ethiopian Boran cattle for meat and milk production". IPMS (Improving Productivity and Market Success) of Ethiopian Farmers Project Working Paper 26. Nairobi, Kenya, ILRI; 2011.

28. G. Shiferaw, "Reproductive and productive performance of Kereyu Sanga cattle in Fentalle District of Oromia Region, Ethiopia". Journal of Cell and Animal Biology; Vol. 8(2), pp. 28-33, February 2014. DOI: 10.5897/JCAB2014.0404

29. D. Genzebu, M. Hailemariam and K. Belihu, "Morphometric characteristics and livestock keeper perceptions of "Arado" cattle breed in Northern Tigray, Ethiopia". Livestock Research for Rural Development 24 (1) 2012.

30. T. Endashaw, D. Tadelle, H. Aynalem and M. Woudyalew, "Characterization of Mursi Cattle Breed in Its Production Environment, in Salamago Wereda, South-West Ethiopia”. MSc Thesis Abstracts, School of Animal and Range Sciences of Alemaya University, Volume I (1980-2013); 2011.

31. H. Mekonen, "Evaluation of growth and reproductive performance of Borana cattle and their crosses with Friesian at Abernossa, Ethiopia". MSc. Thesis, Alemaya University of Agriculture, Dire Dawa, Ethiopia; 1987.

32. G. Yohannes, Y. Zelalem, B. Gizachew, G. Alemu and D. Sendros, "Milk yield and reproductive performance of Borana cows and growth rate of their calves under partial suckling method". In: Proceeding of the 9th National Conference of Ethiopian Society of Animal Production (ESAP). Addis Ababa, Ethiopia. Aug 30-31, 2001.

33. S. Amsalu, "Growth performance of Boran cattle and their Friesian crosses in Ethiopia". Proceeding of 11th Annual conference of the Ethiopian Society Animal Production (ESAP). Addis Ababa, Ethiopia. August 28-30, 2003.

34. H. Aynalem, B. K. Joshi, A. Workinehi, T. Azage and A. Singh, "Genetic evaluation of Ethiopian Boran cattle and their crosses with Holstein Friesian for growth performance in central Ethiopia". J. Anim.Breed. Genet. ISSN 0931-2668; 2010.

35. H. Demissu, B. Fekadu and D. Gemeda, "Early Growth and Reproductive Performances of Horro Cattle and their F1 Jersey Crosses in and around Horro-Guduru Livestock Production and Research Center, Ethiopia". Sci. Technol. Arts Res. J., July-Sep 2013, 2(3): 134-141; 2013.

36. M. Getinet, A. Workneh and B. P. Hegde, "Growth and reproductive performance of Ogaden cattle at Haramaya University, Ethiopia”. Ethiopian Journal of Animal Production (EJAP). 9(1):13-38; 2009. 
37. S. Asheber, "Evaluation of the reproductive and pre-weaning growth performance of Fogera cattle and their $F_{1}$ Friesian crosses at Andassa cattle Breeding Station". MSc thesis, Alamaya University of Agriculture, Ethiopia. 101 pp; 1992.

38. B. Almaz, "Genetic parameter estimation of growth and reproduction traits of Fogera cattle at Metekel Ranch, Amhara Region, Ethiopia". MSc thesis, Bahir Dar University college of Agriculture and Environmental science, Bahir Dar, Ethiopia. Pp 108; 2012.

39. H. Abera, S. Abegaz and Y. Mekasha, "Genetic parameter estimates of pre-weaning weight of Horro (Zebu) and their crosses with Holstein Friesian and Jersey cattle breeds in Ethiopia". International Journal of Livestock Production; Vol. 2(6), pp. 84-91, June 2011.

http://www.academicjournals.org/IJLP

40. M. A. Afroz, M. A. Hoque and A. K. F. H. Bhuiyan, "Estimation of heritability for growth traits of Red Chittagong cattle in a nucleus herd". The Bangladesh Veterinarian (2011) 28(1): 39-46; 2011. 